\title{
レーザー光によるサラダナ栽培実験
}

\author{
森 康裕 $^{1)}$ ・高辻正基 ${ }^{2)}$ \\ 1)東海大学理学部化学科 259-1292 神奈川県平塚市北金目 1117 \\ 2) 東海大学開発工学部生物工学科 410-0395 静岡県沼津市西野 317
}

\section{Growth Experiment in Lettuce using Laser Light}

\author{
Yasuhiro MORI ${ }^{1)}$ and Masamoto TAKATSUJI ${ }^{2)}$ \\ ${ }^{1)}$ Department of Chemistry, Faculty of Science, Tokai University, \\ Kita-Kaname 1117, Hiratsuka, Kanagawa 259-1292, Japan \\ ${ }^{2)}$ Department of Biological Science and Technology, School of \\ High-Technology for Human Welfare, Tokai University, Nishino 317, \\ Numazu, Shizuoka 410-0395, Japan
}

\begin{abstract}
Photosynthetic rate, relative growth rate and vitaminC contents were measured in lettuce cultivated under red and blue lasers and the results were compared with those cultivated under light emitting diodes(LED). It was found that lettuce grew fairly healthily under red laser diode $(650 \mathrm{~nm})$ and blue laser $(442 \mathrm{~nm})$ with $\mathrm{R} / \mathrm{B}$ ratio 10 . However, both photosynthetic rate and growth rate rather diminished compared with LED cases. As for vitaminC contents, the result was about the same as LED cases.
\end{abstract}

Keywords : photosynthetic rate, relative growth rate, vitaminC content, laser, LED, lettuce

\section{緒 言}

近年, 完全制御型植物工場の新しい光源として各所で 可視発光ダイオード (LED) を使用した植物栽培実験の 研究が行われている1 3). また可視半導体レーザーダイ オード(LD)を使用した植物栽培実験が始められてい る ${ }^{4 \sim 7)}$. これらの光半導体素子は従来光源に比べて, (1) 発光波長をクロロフィルの吸収ピークと光形態形成の強 光反応の作用スペクトルのピークにほぼ一致させられる, (2)熱放射がない，(3)小型軽量である，(4)長寿命である， (5)低電圧駆動である, (6)パルス照射が可能である, とい う利点がある.さらに LD の場合は高効率, 高出力, 電 流で直接変調可能という利点が加わる.

赤色 LD は DVD(Digital Versatile Disc)の光ピック

2000 年 8 月 21 日受付

2000 年 10 月 20 日受理
アップ部分に広く採用されている. 赤色 LD の開発だけ でなく,さらに記憶密度の増大を目指して青色 LD の開 発も急速に進み実用化も近い. DVDが広く普及した暁 には, これら LD の大幅なコストダウンが図られ, 植物 栽培用光源として使われる可能性がある.

前報6)では LED の組み合わせおよび, 赤色 LD と青 色 LED を組み合わせてサラダナの成長率, 光合成速度, クロロフィル含量, 気孔コンダクタンスなどを測定した 結果を報告した. また山崎ら ${ }^{7)} 680 \mathrm{~nm}$ の赤色 LD の みによるサラダナの栽培実験を行い高圧ナトリウムラン プによる栽培と比較した。

本論文では, DVD 用の赤色 $\mathrm{LD}(650 \mathrm{~nm})$ と青色の $\mathrm{He}$ $-\mathrm{Cd}$ レーザー $(442 \mathrm{~nm})$ を用い, 前報より広い条件下で レーザー光のみによるサラダナの栽培実験を行った.す なわち, 相対成長率, 光合成速度, 気孔コンダクタンス, ビタミン C 含量などの成長指標に関して基本的なデー 夕をとり, 前報の結果と比較しながらレーザー光が植物 
成長に与える影響を調べた。これらの成長指標は成長の 量 (相対成長率, 光合成速度), 成長の状態(気孔コンダ クタンス)および成長の質(ビタミン C 含量)に対する基 本的な量である。

\section{材料および方法}

\section{1. 試 料}

サラダナ(Lactuca sativa cv. “Natsuyo-Saradana”)の コーティング種子を, 水耕用ウレタンキューブに播種し 育苗室で 12 日間育苗した (蛍光灯により光量子束密度 $150 \mu \mathrm{mol} / \mathrm{m}^{2} \mathrm{~s}$, 気温 $22 \sim 25^{\circ} \mathrm{C}$, 日長 $17 \mathrm{~h}$ ). そして葉数 $2 \sim 3$ 枚で全生体重が $2 \mathrm{~g}$ 程度のものを選抜した. 培養液 は大塚 1 号, 2 号それぞれ $0.75 \mathrm{~g}, 0.50 \mathrm{~g}$ を水 $1 l$ に溶 解し, pH6. $0 \pm 0.5, \mathrm{EC} 1.2 \pm 0.1 \mathrm{mS} / \mathrm{cm}$ に調整したも のを使用した.

\section{2. 光 源}

\section{（1）赤色 LD と青色レーザーの組み合わせ}

使用した赤色 LD は DVD-ROM の用途に開発された 発振波長 $650 \mathrm{~nm}$, 光出力 $10 \mathrm{~mW}$ のものである.これを プリント基盤上の $15 \mathrm{~cm} \times 14 \mathrm{~cm}$ の範囲に 3 個直列 $\times 6$ 個並列に並べ，サラダナに均一に照射するようにした。 LD の駆動回路には光出力を一定に保つことができる APC 回路を採用した. LD は温度によってその特性(波 長, 動作電流)が変化するために，プリント基盤上に冷 却用のペルチェ素子を固定しその上にファンをのせ, 冷 風をLD に送るようにした，実験中，電圧や熱によって $\mathrm{LD}$ の実際の発振波長が基準波長より $10 \mathrm{~nm}$ 程度伸びる 傾向があったので, 波長別光エネルギー分析装置 (LI$1800 \mathrm{C}$, Licor 社) を使用し, 波長がほぼ $650 \mathrm{~nm}$ になる ように制御した。

青色レーザー光は, 白色 $\mathrm{He}-\mathrm{Cd} レ ー サ ゙ ー$ 光 $(\mathrm{KL}-450$, (株) 小系製作所) から青色の波長光のみを選択して透過 させるダイクロイックフィルター(選択透過膜)を用いて 得られた成分 (波長 $442 \mathrm{~nm}$, 光出力 $43 \mathrm{~mW}$ ) である.ま たこの青色レーザー光は，凹レンズを 2 枚使用して拡散 させ，サラダナの側方から照射した。

\section{（2）赤色 LD と青色 LED の組み合わせ}

青色 LED については日亜化学工業(株)の NLPB 500 (中心波長 $450 \mathrm{~nm}$, 半值幅約 $70 \mathrm{~nm}$, 出力 $3 \mathrm{~mW}$ ) を使用 した。これをプリント基盤上の先ほどと同じ範囲に LD を 3 個直列 $\times 3$ 個並列，青色 LED を 10 個直列 $\times 4$ 個並 列にして, 赤色 LD の列と青色 LED の列を交互に並べ た．Fig. 1 に栽培の様子を示すように，基盤を 2 枚使用 した.

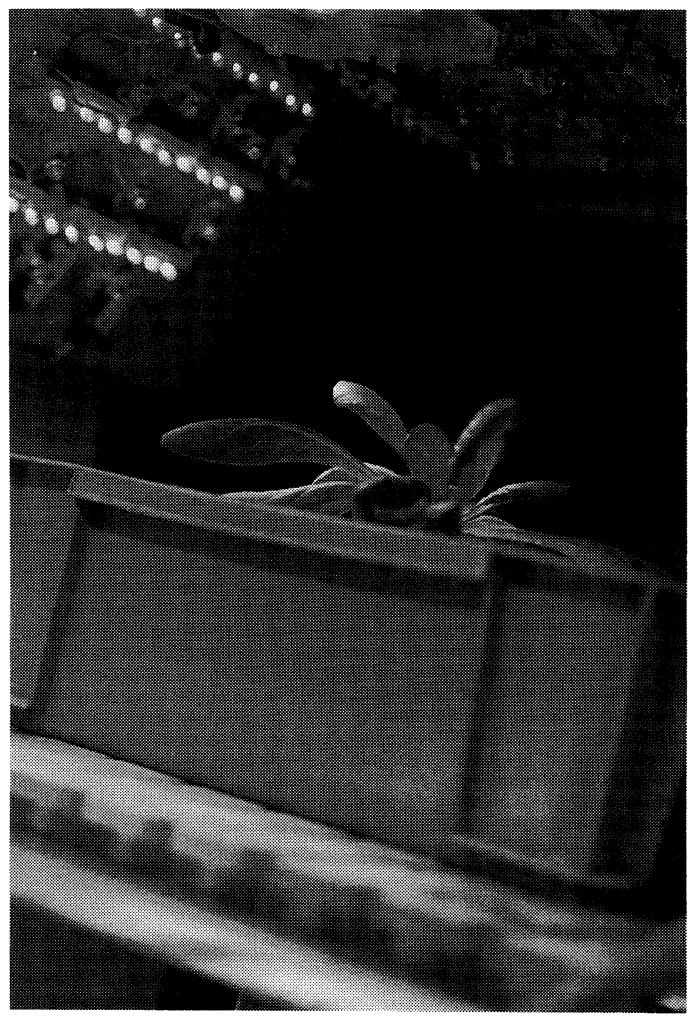

図 1 赤色 LD と青色 LED 照射下のサラダナの成育

Fig. 1 Growth of lettuce under the illumination of red $L D$ and blue $L E D(R / B$ ratio 10$)$

\section{（3）赤色 LED と青色 LED の組み合わせ}

赤色はスタンレー電気の $\mathrm{H} 2000 \mathrm{~L}$ (中心波長 $660 \mathrm{~nm}$, 半值幅約 $25 \mathrm{~nm}$, 出力 $7 \mathrm{~mW}$ ) 使用した. プリント基盤 上の $15 \mathrm{~cm} \times 12 \mathrm{~cm}$ の範囲に赤色 LED を 10 個直列 $\times 10$ 個並列，青色 LED を 10 個直列 $\times 10$ 個並列に配置し， 赤色の列と青色の列が交互になるようにした。

\section{(4) 単色 LED}

赤色と青色 LED については上述のものを使用し，緑 色には日亜化学工業(株)の NSPG 500 S(中心波長 525 $\mathrm{nm}$, 半値幅約 $40 \mathrm{~nm}$, 出力 $4 \mathrm{~mW}$ )を使った. それぞれ, プリント基盤上の前述と同じ範囲の中で 10 個直列 $\times 20$ 個並列に配置した。

\section{3. 栽培条件}

栽培は主に赤色 $\mathrm{LD}$ と青色レーザーの組み合わせ $(\mathrm{R} /$ $\mathrm{B}=10) ， お よ ひ ゙$ 赤色 LD と青色 LED の組み合わせ $(\mathrm{R} /$ $\mathrm{B}=5,10,20)$ を使って行った。ここで $\mathrm{R} / \mathrm{B}$ とは，赤と 青の比率を光合成有効光量子束密度で表した量である. ビタミン C 含量測定の場合のみは赤色，緑色，青色の 各単色 LED 光についても実験した。それぞれの基盤の 
周囲 3 方向を, コンパウンドを混ぜた白色のペンキで塗 ったプラスチックの板で囲って反射率を高めた。

いずれの場合も栽培トレイ上面の光量子束密度をほほ $50 \mu \mathrm{mol} / \mathrm{m}^{2} \mathrm{~s}$ に保った. 栽培装置を気温 $22^{\circ} \mathrm{C}$, 相対湿 度 $70 \%, \mathrm{CO}_{2}$ 濃度 $400 \mathrm{ppm}$, 日長 $17 \mathrm{~h}$ に設定したグロー スキャビネット内に設置した。 以上の環境条件下で全生 体重 $2 \mathrm{~g}$ 程度の試料を水耕栽培した 2 週間後に収穫した。

\section{4. 測 定項目}

\section{（1）相対成長率, 光合成速度, 気孔コンダクタンス}

相対成長率は定植後 14 日目の 3 株の全生体重を測定 して, その平均から求めた. 光合成速度と気孔コンダク タンスについては，それぞれの実験区で収穫直前の 2 株 のサンプルを用意し, 光合成蒸散測定装置 (KIP-9010, (株) 小糸工業)によって 30 回づつ合計 60 回測定したデ 一夕の平均値と標準偏差から求めた.

\section{(2) ビタミン C 含量}

ビタミン C(アスコルビン酸)含量については, 全アス コルビン酸量と還元型アスコルビン酸量を以下の方法で 測定し, 酸化型アスコルビン酸量は両者の差から求め $た^{8)}$. 定量測定のためのサンプルの調整方法は以下の通 りである。

種々の光源の照射下で栽培したサラダナの葉 $0.5 \mathrm{~g}$ を $5 \%$ トリクロロ酢酸(TCA) $5 \mathrm{ml}$ で固定しホモゲナイザ 一によって粉砕し, 遠心分離機で $4^{\circ} \mathrm{C}, 12,000 \mathrm{rpm}$ で 5 分間遠心分離した。この上清を, 還元型アスコルビン酸 と全アスコルビン酸を定量するためのサンプルとして用 いた．還元型アスコルビン酸は，サンプルを $5 \% \mathrm{TCA}$ で 10 倍希釈したもの $1 \mathrm{~m} l$ に, $5 \% \mathrm{TCA} 1 \mathrm{~m} l, \mathrm{EtOH} 1$ $\mathrm{m} l, 0.4 \% \mathrm{H}_{3} \mathrm{PO}_{4}$-EtOH $0.5 \mathrm{~m} l, 0.5 \%$ 4, 7-diphenyl-1. 10-phenanthrolin (Bathophenanthroline, BP)-EtOH 1 $\mathrm{m} l, 0.03 \% \mathrm{FeCl}_{3}$-EtOH $0.5 \mathrm{~m} l$ の順に加え合計 $5 \mathrm{~m} l$ と

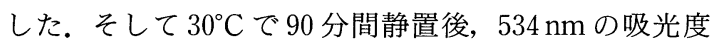
を分光光度計で測定し, 標品 $(\mathrm{L}(+)$ アスコルビン酸)を 使用して作成した検量線から求めた。

全アスコルビン酸量については, サンプルを $5 \%$ TCA で 10 倍希釈したもの $1 \mathrm{~m} l$ に, $0.06 \%$ dithiothreitol(DTT) - EtOH を $0.5 \mathrm{ml}, \quad \mathrm{Na}_{2} \mathrm{HPO}_{4}-1.2 \mathrm{~N}$ $\mathrm{NaOH} 1 \mathrm{~m} l$ の順に加えて $\mathrm{pH}$ 7〜8 亿調整した. こうし て酸化型アスコルビン酸を還元するために室温で 10 分 間静置した。その後, 還元剤の過剩な反応を止めるため に $0.24 \% \mathrm{~N}$ - ethylmaleimide - EtOH0. $5 \mathrm{~m} l$ を加え, $20 \%$ TCA $0.5 \mathrm{~m} l$ でpH 1〜2 亿調整した. 還元後は還 元型アスコルビン酸量の測定と同様に行った.

\section{結果および考察}

\section{1. 相対成長率}

赤色 LED 単色，赤色 LED と青色 LED の組み合わせ, 赤色 $\mathrm{LD}$ 単色, 赤色 $\mathrm{LD}$ と青色 $\mathrm{LED}$ の組み合わせ, お よび赤色 LD と青色レーザーの組み合わせに対するサラ ダナの相対成長率を測定した結果を Fig. 2 に示す。こ の結果を見ると, 同じ $\mathrm{R} / \mathrm{B}=10$ で比較して赤色 $\mathrm{LD}$ と 青色 LED 使用する場合は, 赤色と青色両方とも LED の場合より $30 \%$ 相対成長率が低く, また赤色 LD と青色レーザーで栽培した場合は同じく $40 \%$ 低くなっ た. 赤色, 青色とも LED の場合は $\mathrm{R} / \mathrm{B}=10$ のときが 最大であるのに対して, 赤色に LD を使用した場合には 青色を多く含むほど相対成長率が高い結果が得られた。 これは，レーザーの鋭い単色性が青色 LED と併用する ことで放射スペクトルに幅ができ光合成の光利用効率が 上がったためだと考えられる。

山崎ら ${ }^{7}$ は, $680 \mathrm{~nm}$ の赤色 $\mathrm{LD}$ と同じ光量子束密度の 高圧ナトリウムランプによる成長を比較しているが, LD による成長は大幅に低い結果を報告している。両者 のスペクトルの違いはあるが, 単色性の影響が考えられ る.というのは, 筆者らの研究では同じ波長で比較して スペクトル幅の広い LED のほうが LD よりも成長がか なり大きかったからである。

\section{2. 光合成速度}

Fig. 3 は Fig. 2 と同じ照射条件下で, みかけの光合成 速度を測定した結果を示す。この結果を見ると赤色 LD と青色 LED の場合, 赤色と青色両方とも LED の場合 と同様に, 光合成速度は青色の比率が高い $\mathrm{R} / \mathrm{B}=5$ が最 も高く，次いで $\mathrm{R} / \mathrm{B}=10,20$ の順となった。これは, 前報 ${ }^{6} の$ 単色 LED によって栽培した場合の光合成速度

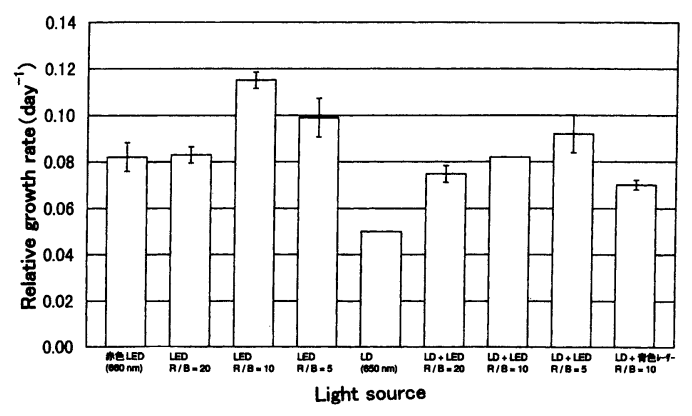

図 2 LED およびレーザー照射下のサラダナの成長率

Fig. 2 Growth rates of lettuce under the illumination of various spectra of LED and laser 


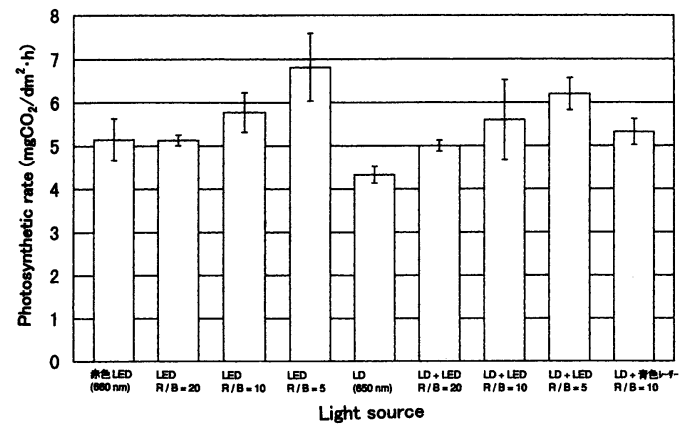

図 3 LED およびレーザー照射下のサラダナの光合 成速度

Fig. 3 Photosynthetic rates of lettuce under the illumination of various spectra of LED and laser

で, 青色がもっとも高かったことに関係している.一方, 成長率に関しては赤色の場合がもっとも高かったので, 光合成速度と成長率の結果に違いが出たと考えられる.

次に, 赤色 LD と青色レーザーの場合の光合成速度は, 青色に LED を使用する場合より約 $8 \%$ 低かった。それ について以下簡単に考察する.

よく知られているように, 光合成反応は成育に本質的 であり，その作用スペクトルをみると植物は幅広い波長 領域を受けて反応しているのがわかる，自然界では，可 視光全体をカバーする太陽光を使って光合成をしている. したがって, 単色性の光源よりもある程度のスペクトル 幅のある光源あるいは, 複数のスペクトルの混ざった光 源の方が光合成の光利用効率が高まると考えられる. 実 際, $680 \mathrm{~nm}$ より長波長の単色光と短波長の単色光を同 時に照射すると別々に照射したときの光合成速度の和よ りも大きくなるというエマーソン効果 ${ }^{9}$ が知られている.

\section{3. 気孔コンダクタンス}

Fig. 4 はFig. 2, Fig. 3 と同じ照射条件下で, 気孔コ ンダクタンスを測定した結果を示す。本実験のように光 以外の栽培環境が同じ場合, 気孔コンダクタンスが高い ことは，ある特定の波長や光源の種類に対して気孔開度 が高く, 蒸散や光合成が活発に行われていることを意味 する。

全体的に光合成速度と同じ傾向になっているが，赤色 と青色の混合光ではレーザーを使用すると気孔コンダク タンスが全体的に低くなった。 したがって気孔の開閉に 対しても，鋭い単色光は不利であると考えられる。また， 赤色と青色両方とも LED の場合と赤色 LD と青色 LED の組み合わせでは, 青色の比率を高くすると気孔コンダ クタンスが高くなった.この実験結果は, 前報 ${ }^{6)}$ 単色

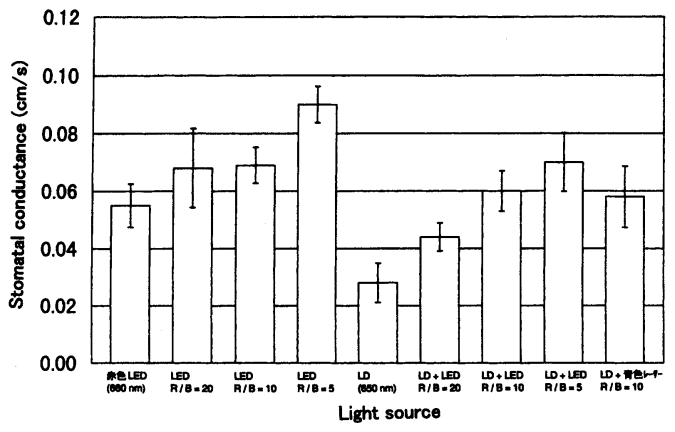

図 4 LED およびレーザー照射下のサラダナの気孔 コンダクタンス

Fig. 4 Stomatal conductances of lettuce under the illumination of various spectra of LED and laser

LED によって栽培した場合の気孔コンダクタンスが青 色の場合にもっとも高かった結果と一致する.

\section{4. ビタミンC 含量}

Fig. 5 に種々の波長の LED, 赤色 LED と青色 LED の組み合わせの場合，および赤色 LD と青色レーザーを $\mathrm{R} / \mathrm{B}=10$ の比率で組み合わせた場合のサラダナのビタ ミン $\mathrm{C}$ 含量を測定した結果を示す。単色光については 青色の場合のビタミン C 含量が最大だった. 赤色と青 色両方とも LED の場合, 光合成速度と同様に $\mathrm{R} / \mathrm{B}=5$ の場合が最も含量が高く, 次いで $\mathrm{R} / \mathrm{B}=10,20$ の順と なった。また，レーザ光のみの場合に最も総ビタミン $\mathrm{C}$ 含量が多くなった. 全体的に還元型より酸化型の割合が 大きく, とくに単色 LED 光やレーザー光で栽培した場 合がそうなった。

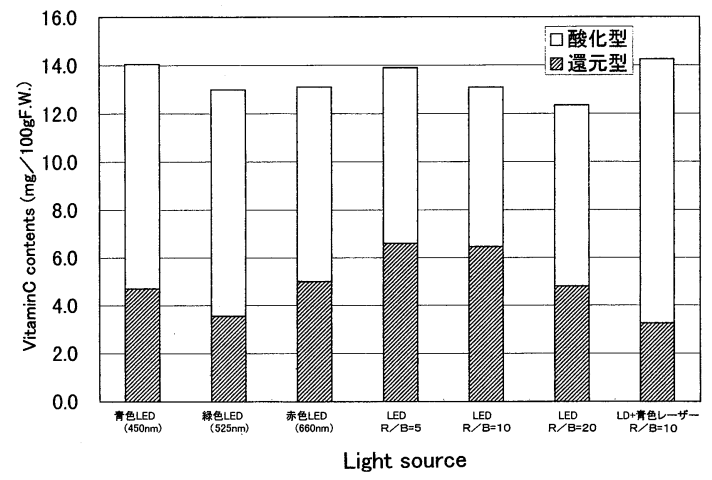

図 5 LED およびレーザー照射下のサラダナのビタ ミン C 含量

Fig. 5 VitaminC contents of lettuce under the illumination of various spectra of LED and laser 
植物はストレスを受けるほど，生体防御機能が働きア スコルビン酸は還元型から酸化型に変換されると考えら れている.また, 総ビタミンC 含量も増えると考えら れる，青色 LED やレーザーで栽培したサラダナの酸化 型が多いのは, 光の波長が短かかったり, 鋭い単色性が 植物にストレスをかけるためだと考えられる。

\section{5. 生育状況}

赤色 $\mathrm{LD}$ と青色レーザーを $\mathrm{R} / \mathrm{B}$ 比 10 で併用し, 光量 子束密度が $50 \mu \mathrm{mol} / \mathrm{m}^{2} \mathrm{~s}$ という低い強度で生育させた 場合のサラダナの生育状況を Fig. 6 に示す。これを見 ると葉はやや細長く, 徒長傾向になったものの比較的健 全に生育することがわかった. また, 全体的に赤色 LD を使用すると, 数枚の葉が下向きに巻き込む現象があっ た.これは, レーザー光が葉上に均一に拡散されていな いためだと考えられる。

\section{結言}

本研究ではレーザー光のみによってサラダナを栽培し，

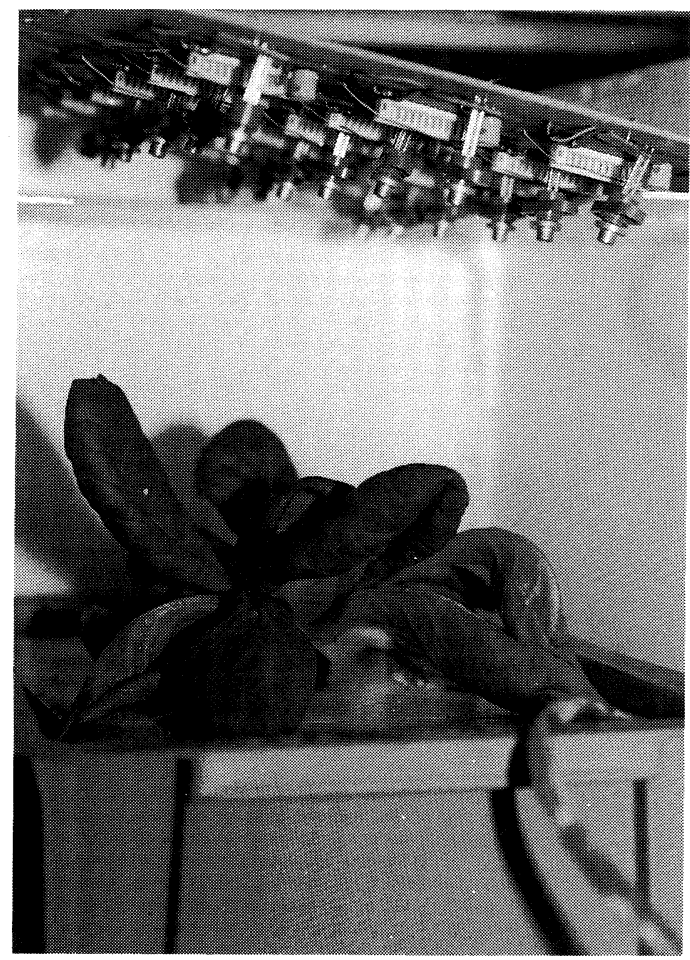

図 6 赤色 LD と青色レーザー照射下のサラダナの成 育

Fig. 6 Growth of lettuce under the illumination of red $L D$ and blue laser $(\mathrm{R} / \mathrm{B}$ ratio 10$)$
成長率, 光合成速度, 気孔コンダクタンス, ビタミン C 含量を測定し LED の場合と比較した. 赤色 LD と青色 レーザーによる栽培は, 赤色と青色両方とも LED の場 合や赤色 LD と青色 LED の組み合わせの場合より成長 率, 光合成速度, 気孔コンダクタンスとも若干落ちるこ とがわかった．これはレーザー光の放射スペクトルの幅 が極めて狭いためだと考えられる。ただし，ビタミンC 含量に関しては変わらなかった。

今回の実験では，レーザーによりサラダナを比較的健 全に生育させることができた. 今後, DVDなどの普及 により LD の高出力化, 低価格化が進めば, 植物栽培用 の光源として利用可能であると考える. さらに, 高出力 のレーザー光をパルス照射することにより, 光合成の暗 反応によって律速されずに, 効率よい栽培が可能になる と考えられる。

\section{謝辞}

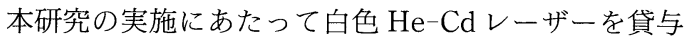
いただいた(株)小系製作所と，LED を提供いただいた (株) シーシーエスに御礼申し上げる。また東海大学の高 山眞策教授と三菱化学 (株)の渡辺博之氏には, アスコル ビン酸の実験手法等について有益な助言をいただいたこ とに感謝する.

\section{引用文献}

1）渡辺博之：LED 光源の植物栽培利用，植物工場 実用化ビジネス研究部会資料, 日本工業技術振興 協会 (1995)

2) 渡辺博之：LED光源の植物工場への適用, SHITA Report, $11: 31-41$ (1996)

3）渡辺博之：LED 光源の植物工場への応用, SHITA Report, 12 : 14-23(1997)

4）高辻正基，森 康裕：レーザー植物工場，植物工 場ハンドブック (高辻正基編集), 東海大学出版会, pp.80-85(1997)

5）社団法人 レーザー学会編：レーザーの植物工場 への応用小特集号, レーザー研究，25：831-854 (1997)

6）森 康裕, 高辻正基：LED と LD 光がサラダナ 生育に及ぼす影響, 植物工場学会誌, 11(1)：4649 (1999)

7）山崎 文，土屋広司，宮島博文，本間孝宜，菅 博文：半導体レーザー光がサラダナ生育に及ぼす 影響, 植物工場学会誌, 12(2)：93-98(2000)

8) Arakawa, N., Tsutsumi, K., Sanceda, N., Kurata, T. and Inagaki, C. : A Rapid and Sensitive Method for the Determination of Ascorbic Acid 
using 4,7-Diphenyl-1, 10-phenanthroline, Biochem., 45(5) : 1289-1290 (1981)
9）加藤 栄: 光合成入門, 光生物学シリーズ, 共立 出版(株), pp. 15-16(1973) 